\title{
Introduction: Transplantation of the Normal Mammary Gland: Early Evidence for a Mammary Stem Cell
}

\author{
Margaret C. Neville
}

Published online: 5 August 2009

(C) Springer Science + Business Media, LLC 2009

In 1951 the State of California began to provide support for cancer research at the University by providing funds for a colony of mice with reliable genetic characteristics. The Cancer Research Genetics Laboratory was established at Berkeley to house this effort and Kenneth B DeOme became the first director and Professor of Zoology. He came to this position with a wealth of experience including the ministry in his early years, a $\mathrm{PhD}$ in zoology (field, genetics) under Samuel Jackson Holmes, and 12 years as a veterinary pathologist on the Davis campus of the University of California.

DeOme was able to attract many talented individuals to this laboratory including Howard Bern, who had a background in endocrinology, David Weiss, an immunologist, Dorothy Pitelka, who brought exceptional skills in electron microscopy, Satyabrata Nandi, a tumor biologist and endocrinologist, and Phyllis Blair, a tumor virologist and endocrinologist. A second generation included many students who have gone on to distinguished careers in mammary biology including Sefton Wellings, Leslie Faulkin, Charles Daniel, Robert Cardiff, Gloria Heffner, Daniel Medina, Sandra Z. Haslam and Lakshamanaswamy Rajkumar. All began to contribute to the laboratory's program on breast cancer. It soon became clear that the name of the laboratory was too restrictive and it was changed to the Cancer Research Laboratory, the name it bears today as a multifaceted cancer research laboratory independent of a medical school.

The initial focus of the research laboratory was on the hyperplastic alveolar nodule, or HAN, a lesion containing viral particles that they discovered in the $\mathrm{C} 3 \mathrm{H}$ strain of

M. C. Neville $(\bowtie)$

UCDenver School of Medicine,

Aurora, CO 80220, USA

e-mail: peggy.neville@ucdenver.edu mice [1]. They postulated that these lesions were the precursors to the mammary tumors that also developed in this strain, but in order to prove this contention they needed to transplant the HANs into a site where they could observe the development of a tumor from an already identified nodule. Dan Medina, who was a student of Ken DeOme, describes DeOme as becoming increasingly frustrated by the failure of the HANs to grow or develop into tumors when transplanted under the skin of the mouse from which they had been removed. One day, sitting over the microscope at the low tables which were the lab benches at the time, DeOme was observing the mammary gland of very young mice and realized that the actual epithelial tissue had grown only to the level of the lymph node, leaving a large area of the mammary fat pad naked, as it were. He quickly realized that he could remove the ductal tissue surgically, leaving only a fat pad devoid of epithelial elements. He transplanted the HANs into this fat pad and watched as they developed into tumors. This experiment, published in 1959 [2], showed 1) that the fat pad was necessary for growth of normal and hyperplastic tissue, 2) that transplanted normal tissue can grow out in the fat pad and form a normal gland, and 3) that hyperplastic nodules, given sufficient time following growth to fill the fat pad, can become tumors. The transplantation technique has been used in myriads of experiments up to the present to characterize both normal mammary development and tumor growth, including the effects of genetic mutations on these processes [3-6].

Because of its length and availability we were unable to reprint the DeOme article in this issue. The technique described was, however, used to great effect by Charles Daniel, who serially transplanted small tissue fragments from both normal glands and HANs. The normal tissues were able to generate up to 5 generations of normal 
mammary epithelium before eventually petering out, whereas the HANs were still going after 8 years, or more than 30 generations, suggesting to the authors that the normal tissues have a finite growth capability, but that the precancerous HANs have an unlimited growth potential. This article is reprinted here. An important point indicating specific microenvironment requirements for mammary growth was that both types of transplant required the cleared fat pad. This concept has been expanded to great effect in the breast cancer field as reviewed by Schedin and her colleagues $[7,8]$. The other implication of this work is that multipotent stem cells capable of reconstituting the entire gland exist in the mammary gland. An interesting article that links these two concepts is found in the work of Boulanger and Smith on the role of the stem cell niche in preserving the life span of the mammary progenitor cell $[9,10]$.

\section{References}

1. Pitelka DR, Bern HA, DeOme KB, Schooley CN, Wellings SR. Viruslike particles in hyperplastic alveolar nodules of the mammary gland of the $\mathrm{C} 3 \mathrm{H} / \mathrm{He}$ CRGL mouse. J Natl Cancer Inst. 1958;20:541-53.

2. DeOme KB, Faulkin LJ, Bern HA, Blair PB. Development of mammary tumors from hyperplastic alveolar nodules transplanted into gland-free mammary fat pads of female $\mathrm{C} 3 \mathrm{H}$ mice. Cancer Res. 1959;19:515-525.

3. Medina D. Premalignant and malignant mammary lesions induced by MMTV and chemical carcinogens. J Mammary Gland Biol Neoplasia. 2008;13:271-7.

4. Farnie G, Clarke RB. Mammary stem cells and breast cancerrole of Notch signalling. Stem Cell Rev. 2007;3:169-75.

5. Sternlicht MD, Sunnarborg SW. The ADAM17-amphiregulinEGFR axis in mammary development and cancer. J Mammary Gland Biol Neoplasia. 2008;13:181-94.

6. Molyneux G, Regan J, Smalley MJ. Mammary stem cells and breast cancer. Cell Mol Life Sci. 2007;64:3248-60.

7. McDaniel SM, Rumer KK, Biroc SL, Metz RP, Singh M, Porter $\mathrm{W}$, et al. Remodeling of the mammary microenvironment after lactation promotes breast tumor cell metastasis. Am J Pathol. 2006;168:608-20.

8. Schedin P, Borges V. Breaking down barriers: the importance of the stromal microenvironment in acquiring invasiveness in young women's breast cancer. Breast Cancer Res. 2009;11:102.

9. Boulanger CA, Smith GH. Reprogramming cell fates in the mammary microenvironment. Cell Cycle. 2009;8:1127-32.

10. Booth BW, Boulanger CA, Smith GH. Stem cells and the mammary microenvironment. Breast Dis. 2008;29:57-67. 